\title{
Technical elements in Hungarian sabre fencing manuals
}

\author{
Mátyás Miskolczi \\ Independent researcher, Ars Ensis, Hungary \\ matyas.miskolczi@gmx.net
}

\begin{abstract}
This research aims to collect technical elements identified in Hungarian sabre manuals. At the current stage of research they were assembled in a table, creating a map of elements. The research itself is in an initial phase, this research note is here to share first results.
\end{abstract}

Keywords - sabre, Hungarian, map of technical elements, research note

\section{AIM OF THE WORK}

This research aims to create a map of fencing techniques used by Hungarian sabre fencing manuals to help HEMA researchers in identifying similarities or differences to nonHungarian but probably related sources. Since Hungarian language is not widely spoken by most of the HEMA researchers, this paper aims to group technical elements and provide them with English labels. It is also to be considered that sources processed here may use different Hungarian names for the same technical element or they may use the same name for different variations of the similar technique. This research aims to structure them to create a map of Hungarian sabre techniques which have a written evidence available.

\section{SCOPE AND SOURCES}

Sources were selected by the following criteria:

1. It has to be a fencing manual about sabre, it needs to be a primary source

2. It needs to be published by a Hungarian fencing master or teacher

3. It needs to be considered as HEMA

The first criteria is rather easy to understand, instead of giving a definition on a "fencing manual" it should be defined what is to be considered as out of scope. Newspaper articles about duels, descriptions of the work of a fencing master (be it a criticism or a supporting description), or even a police or military event record are out of the scope of this work since they do not describe a complete and coherent technical system of the given weapon, also may not be written by a fencer.

The second one is hard to apply on some papers. Hungarian language is actually an official language in Hungary since 1836. Looking back on the Hungarian history it's easy to understand that until the first half of the $19^{\text {th }}$ Century many papers, books and articles written by Hungarian authors were published in German rather than Hungarian and many papers have ended up in libraries or collections in Vienna. The first known sabre manual 
published in Hungarian language was written by János Domján (1839). In the $19^{\text {th }}$ century authors' names were not a reliable indication nationality, since many nationalities were mixed in the Austro-Hungarian Monarchy and especially among fencers French or Italian names were quite common. It means that the language of the manual, the background information on the author and the place of publication may be indications to decide if the given paper may count as Hungarian or not. In frames of this research eight sources were processed, seven of them are written in Hungarian. The only one written in German (Gustav Ritter von Arlow - Franz Litomyský: Systematisches Lehrbuch für den Unterricht im Säbelfechten aus der Hoch-Tierce-Auslage, 1894) is co-published by a Hungarian fencing teacher Gusztáv Arlow who has published a different manual in Hungarian too (1902).

The question of "what is HEMA" (HEMA = Historical European Martial Art) is extensively discussed in HEMA-related articles. This research does not aim to discuss this question in details but leaves the possibility of later extension open on further works. Manuals which are definitely dedicated on Olympic fencing are out of scope for this research.

Processed sabre manuals:

1. Domján, János: Ví-tan (Buda, 1839)

2. Sebetic, Rajmund: A Kard - Vívás (Pozsony - Buda, 1885)

3. Murz, Frigyes: Vítőr-, Kard- és Párbajvívás (Debrecen, 1890)

4. Chappon, Samu: A vívás művézsetének elmélete (Pécs, 1891)

5. Chappon, Károly: Kardvívás (Debrecen, 1893)

6. Arlow - Litomysky: Systematisches Lehebuch für den Unterricht im Säbelfechten aus der Hoch-Tierce-Auslage (Prag, 1894)

7. Arlow, Gusztáv: Kardvívás (Budapest, 1902)

8. Leszák, Károly: Kardvívás (Budapest, 1906)

\section{METHODOLOGY}

Fencing techniques were collected manually from the processed papers by listing them when reading through each book. All items referring to any part of the fencer's body, to attacks, parries or movements were listed as a technical element. They were grouped by their aims and the concerned part of the body. Based on the Hungarian (and also on the often applied Italian, French or German) names of the items they were identified and listed under the title of the given source. The consolidated list of technical elements and the sources they are contained in give up a matrix which is to be considered a rather complete map of the technical elements of the Hungarian sabre manuals. A grouping was also added to help sorting and classification. Descriptions about the unique elements were used to state if the given element may be identical with a similar one in an other source or not. Small differences were neglected in this phase of the research, the main factor of identifying technical elements was still the naming. It means that in a later phase 
differences between elements with the same name but listed in different sources might be discussed if they should be considered as a subtype or as a completely different element. Methodological ways to make it happen are still to be identified.

Results are listed and also graphically displayed on a dedicated page of the journal Acta Periodica Duellatorum website. When this research note is published the change log is set clear. Inputs regarding results are welcome, later changes and edits based on inputs may be done which is to be indicated in the change log with timestamp and comment.

\section{CURRENT FINDINGS}

\section{IV.1. The amount of technical elements}

All in all more than 100 elements were already identified. The reason to use the expression "already" refers to the incompleteness of the current research. Regarding the exact number of identified elements it is to be considered that still no exclusive method has been chosen for identifying technical elements and to describe the differences between similar ones. Until this point the number of elements may not be considered as exact.

These limitations are also to be applied on each source processed in the frame of this research. The current number of identified elements regarding each manuals can be considered as an adequate estimation that might represent the amount of elements contained in the given manual. These numbers may refer to the complexity of the system described by their authors. It was common that fencing manuals have not exclusively contained treatises on one weapon but were focusing on their functional usage (mainly duelling), so they have covered beside sabre also epée and some sources have discussed rules of duelling with pistols too. These combined manuals usually do not go in details of advanced usage of sabre but rather stay on basic level. The number of technical elements of sabre in these manuals usually stay between $35-50$ while more complex ones go beyond 60 .

The possible answers on the question what may count as a "technical element" might also influence the amount of identified techniques. At current stage of this research not only attacks, parries and footwork elements were considered as elements but also hand positions, the appel ( $\sim$ sign) or the double (double hit). It can be challenged and/or changed in later phases.

\section{IV.2. Usage of non-Hungarian names}

When assembling the collection of techniques described in Hungarian manuals, their English names - the ones that seemed to be the most identical - were listed. This is a first version based on the current stage of the research. The perfect identification of elements, differentiation between them and identifying their subversions may be a subject of further discussions. In the columns for each manual the elements are listed by their original names 
as they were used in the manual. It means that not only Hungarian expressions are to be found. Not only the German written Arlow-Litomysky (1894) manual contains nonHungarian expressions but merely all of the processed manuals contain at least some elements with German, Italian or French name - some manuals contain more. Some authors have put focus on translating technical elements to Hungarian. They did their best to find a fitting Hungarian expression to the elements used by their non-Hungarian names also in Hungarian fencing halls. It is to be considered that the $19^{\text {th }}$ Century was a quite intensive period of the Hungarian language reform so translating all "foreign" expressions and creating new words were quite common at that time. Nevertheless, many non-Hungarian names are present in the manuals, and they help us to identify possible influences of different sabre fencing traditions that could affect the style described by the author.

Some elements are hard to match with an English one, in these cases one of the original, non-English names were used for identification. By the progress of the research and involving more (non-Hungarian) sources it can be improved.

\section{IV.3. Frequently and rarely described elements}

The list of technical elements involve a set of the most frequent ones, which are present in all or in almost all of the inspected sources. These are usually - not surprisingly - basic elements like cuts and parries in the four usual positions of the hand (prime - seconde - tierce - quarte). Common footwork elements (forward and backward steps, lunge and appel) are also part of this set. However, some elements are described only in one or some of the sources, some of them have unique Hungarian names. In such cases I have tried to find an appropriate English name for them, they may be subject of further verification.

\section{IV.4. Unifying similar elements under one English name}

Returning to the question "what counts as a separate technical element" it's important to come to a widely accepted consensus among researchers of sabre-related sources. At this stage of the research no attempt was made to give a definition on that and the question is open for other researchers' contributions. Finding an acceptable definition would not only allow to identify separate elements but also to group similar ones under main elements defining them as their subversions. It may also imply to exactly define how the different sources describe them (just like hand positions are described by exact angles in some sources, or the way of holding the sabre).

\section{IV.5. Possible further directions of the research}

At current stage of the research all Hungarian sources considered as relevant were processed. Their analysis is at the moment of the submission of this note still in progress. After covering the Hungarian sources also non-Hungarian sources could be added to the map. The map may help to discover similarities, differences and new contexts. 
Comparative analysis may be performed based on language of the names, origin of the sources, time of their publication, and references used in them.

This work may contribute to the improvement and unification of English names of sabre techniques. Also definition of "technical element" and (maybe) definition of supporting categories for other connected expressions like events during a duel (for example: double), distance, greetings, etc. may reach a higher level of agreement.

The collection (also referred to as map) of Hungarian sabre technical elements is accessible here: http://www.actaperiodicaduellatorum.com/sabretechresearch

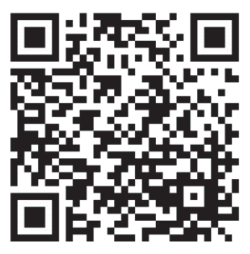

